Check for updates

MSF

Cite this as: $B M J 2021 ; 375: n 3126$ http://dx.doi.org/10.1136/bmj.n3126 Published: 20 December 2021

\title{
Afghanistan's babies and mothers must not be forgotten
}

\author{
MSF's maternity facilities in Afghanistan often make the difference between life and death, says \\ Severine Caluwaerts
}

Severine Caluwaerts,

How to donate
Please give generously to The BMJ's appeal for 2021-22.
Donations can be made at
msf.org.uk/bmj
The 2021-22 appeal is being generously supported by
the Green Room Charitable Trust. Up to $\mathrm{f}_{50} 000$ in
funding has been made available to match donations
received before 31 January 2022. This means that your
support will go even further.
The Afghan Crisis Appeal will fund MSF's work in
Afghanistan, as well as supporting its work in
neighbouring countries.

A few days ago, I helped to save a mother's life. It had seemed like a normal labour: she came into hospital and gave birth, but soon after delivery a complication emerged. Nothing seemed to help at first, but eventually our interventions worked. The mother recovered well and was happy to return home with a healthy baby. As I watched her leave, I reflected on the fact that, without access to the MSF hospital, she likely would have died.

\section{Afghanistan's precarious healthcare system}

MSF's work here in Khost is vital as Afghanistan's health system is extremely fragile. Access to free medical care is hard to come by and most people cannot afford private treatment.

We are the largest provider of maternal healthcare in the province, running one of MSF's busiest maternity hospitals in the world. We saw a dip in patient numbers during the first wave of covid- 19 for a variety of reasons, including a temporary closure, community fears of being infected in hospital, and our infection prevention and control measures that for a time restricted pregnant women from having someone accompany them. We also saw fewer patients towards the end of the conflict earlier this year, as many women were fearful of travelling so had to give birth at home. However, patient numbers have been rising steadily-in October we delivered 1850 babies, approximately one every 24 minutes. The treatment we provide here often means the difference between life and death.

\section{A tragic reality}

Not everyone survives. I remember a few years ago, a mother came to us in cardiac failure during birth. We performed an emergency c-section, but it was too late. As a doctor, the loss of a patient stays with you. Young women are not meant to die from a complication in pregnancy, but this is the tragic reality for many in Afghanistan.
Given the quality of care provided in the MSF facility, the vast majority of our patients survive and go home in a stable condition. Yet elsewhere in the country, the risk of dying in labour is much higher. The dangerous lack of access to healthcare in Afghanistan has been a problem during the many years I have worked here. The needs of women remain the same regardless of politics. Mothers want to survive and they want their children to live. They want their children to be healthy and they want to be healthy themselves.

The healthcare needs of the people we see are, however, becoming more acute. Afghanistan is experiencing a health crisis, with systems made even more vulnerable by the interruptions and cancellations in international aid. A lot of funding has been suspended, with some donors insisting that no money be given to the new government, including the Ministry of Public Health. MSF can carry on as we are funded by private donations, but we are one of the few international organisations providing maternal care in the country.

The increase in the number of patients we're seeing is not only due to changes in the covid-19 situation or the calming of violence, but also the fact that since international funding was suspended, pregnant women have had fewer places to access healthcare as many facilities lack staff and supplies. Mothers will continue to give birth and they will continue to need help, but this help is even more limited than before.

\section{Giving women and babies a chance}

I am a doctor, not a politician. What I see is that the Afghan people are suffering due to the lack of accessible healthcare. It is vital that maternity services continue amid all the uncertainty the country faces.

We are able to give people a chance here. We cannot know what will happen to them in the following months and years. But whenever I say goodbye to the women and babies who have made it through labour safely and are returning home, I am heartened to know that for this mother, for this pregnancy, we have made a difference.

This is my tenth visit to Afghanistan. When people ask me why I keep coming back I always say it is because of the people. I have grown attached to them, especially the Afghan staff who have worked through tremendously difficult situations and remain determined to help mothers and babies survive. They work small miracles here. 
As doctors, we never ask ourselves why we do this work. We know why. We see it every day. We see the appreciation and relief from women who are given somewhere to feel safe and cared for during the most vulnerable moment of their lives.

Afghanistan is desperately in need of financial aid. It needs medicine and investment into its health system. I see the acute suffering of the people here and it pains me to know that it is preventable.

Afghanistan and its mothers and babies must not be forgotten by the international community.

Competing interests: none declared.

Provenance and peer review: Commissioned; not peer reviewed. 